Braz J Med Biol Res, February 2012, Volume 45(2) 172-178

doi: 10.1590/S0100-879X2012007500004

Loss of Y-chromosome does not correlate with age at onset of head and neck carcinoma: a case-control study

L.C. Silva Veiga, N.A. Bérgamo, P.P. Reis, L.P. Kowalski and S.R. Rogatto

The Brazilian Journal of Medical and Biological Research is partially financed by

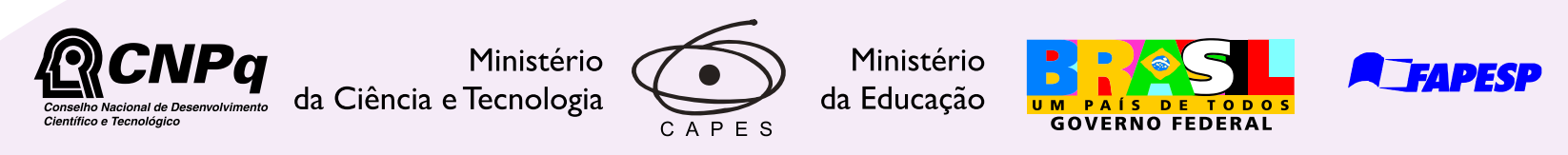

Institutional Sponsors
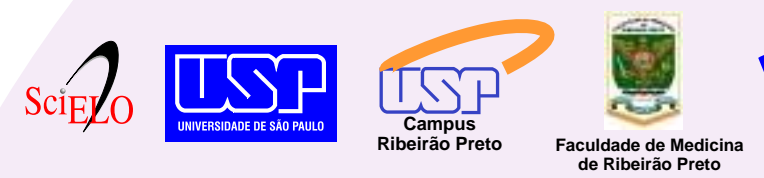

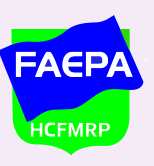

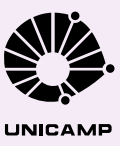

$\oplus$ SHIMADZU

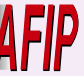

Associação Fundo
de Incentivo
à Pesquisa

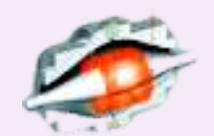
UNICAMP

lore High - Performance MS Orbitrap Technology analitica Thermo 


\title{
Loss of Y-chromosome does not correlate with age at onset of head and neck carcinoma: a case-control study
}

\author{
L.C. Silva Veiga ${ }^{1,2}$, N.A. Bérgamo ${ }^{3}$, P.P. Reis ${ }^{4}$, L.P. Kowalski ${ }^{5}$ and S.R. Rogatto 6,7 \\ ${ }^{1}$ Departamento de Genética, Instituto de Biociências, Universidade Estadual Paulista, Botucatu, SP, Brasil \\ 2Departamento de Clínica Médica, Faculdade de Medicina de Ribeirão Preto, \\ Universidade de São Paulo, Ribeirão Preto, SP, Brasil \\ ${ }^{3}$ Departamento de Biologia Geral, Instituto de Ciências Biológicas, Universidade Federal de Goiás, Goiânia, GO, Brasil \\ ${ }^{4}$ Departamento de Cirurgia e Ortopedia, Faculdade de Medicina de Botucatu, Universidade Estadual Paulista, Botucatu, SP, Brasil \\ ${ }^{5}$ Departamento de Cirurgia de Cabeça e Pescoço e Otorrinolaringologia, Hospital A.C. Camargo, São Paulo, SP, Brasil \\ 6 Laboratório NeoGene, Departamento de Urologia, Faculdade de Medicina de Botucatu, \\ Universidade Estadual Paulista, Botucatu, SP, Brasil \\ ${ }^{7}$ Departamento de Pesquisa, Hospital A.C. Camargo, Fundação Antônio Prudente, São Paulo, SP, Brasil
}

\begin{abstract}
Loss of Y-chromosome has been correlated with older age in males. Furthermore, current evidence indicates that $Y$-chromosome loss also occurs in several human tumors, including head and neck carcinomas. However, the association between $Y$ nullisomy and the occurrence of neoplasias in elderly men has not been well established. In the present study, the association between Y-chromosome loss and head and neck carcinomas was evaluated by comparison to cells from peripheral blood lymphocytes and normal mucosa of cancer-free individuals matched for age using dual-color fluorescence in situ hybridization. Twenty-one patients ranging in age from 28 to 68 years were divided into five-year groups for comparison with 16 cancer-free individuals matched for age. The medical records of all patients were examined to obtain clinical and histopathological data. None of the patients had undergone radiotherapy or chemotherapy before surgery. In all groups, the frequency of $Y$-chromosome loss was higher among patients than among normal reference subjects $(P<0.0001)$ and was not age-dependent. These data suggest that $\mathrm{Y}$-chromosome loss is a tumor-specific alteration not associated with advanced age in head and neck carcinomas.
\end{abstract}

Key words: Fluorescence in situ hybridization; Y-chromosome; Chromosomal abnormalities; Head and neck cancer

\section{Introduction}

Functional genes mapped to chromosome $Y$ can be divided into three distinct groups. The first consists of identical genes on $\mathrm{X}$ - and $\mathrm{Y}$-chromosomes located within the pseudoautosomal region, including those that play a role in metabolic pathways for cell energy and cell surface antigen expression. Recent evidence has suggested the presence of two miRNA mapped to the pseudoautosomal region (1). The second group has homologous but not identical genes on the $\mathrm{X}$-chromosome. They are located in the non-recombinant region of the Y-chromosome (NRY) or male-specific Y-chromosome (MSY). The third group includes genes from the non-recombinant region such as $S R Y$ (sex-determining region $Y$ ). The pseudoautosomal regions present 19 coding genes and the euchromatic re- gion of MSY has 78 genes (1). Although a small number of genes mapped to the Y-chromosome has been described, recent studies have demonstrated their involvement in several diseases as well as in tumors affecting males such as gonadoblastomas (2) and prostate cancer (3). Therefore, the genes mapped to the $\mathrm{Y}$-chromosome have the potential to influence cell proliferation and signaling transduction, or they can regulate gene expression by targeting specific mRNA. In general, Y-chromosome alterations show a great potential for involvement in human cancer (2).

Earlier studies have shown that Y-chromosome loss is a normal phenomenon observed in the bone marrow of elderly males (4-6). Pierre and Hoagland (7) and Sakurai and Sandberg (8) suggested that, although Y-chromosome

Correspondence: S.R. Rogatto, Laboratório NeoGene, Departamento de Urologia, Faculdade de Medicina, UNESP, 18618-000 Botucatu, SP, Brasil. Fax: +55-14-3811-6271. E-mail: rogatto@fmb.unesp.br

Received September 14, 2011. Accepted December 20, 2011. Available online January 20, 2012. Published February 17, 2012. 
loss should be recognized as a common age-related event, the percentage of $Y$ loss is not dependent on age or disease. In 1992, the United Kingdom Cancer Cytogenetics Group (9) concluded that Y-chromosome loss in elderly males was not indicative of malignancy and should not be interpreted as a tumor marker. More recently, Zhang et al. (10) demonstrated that the frequency of Y-chromosome loss was significantly higher in patients with hematological disorders than in patients without such disorders, indicating that loss of the Y-chromosome is associated with a neoplastic process.

Current evidence indicates that Y-chromosome loss occurs in several human tumors, including prostate cancer (11-15), leukemia (16), esophageal carcinoma (17), gastric cancer (18), colorectal carcinoma (19), testicular germ cell tumor $(2,20)$, renal carcinoma $(21,22)$, as well as head and neck carcinomas (4). Recently, Singh et al. (23) demonstrated by large-scale epigenomic analysis the transcriptional potential of all protein-coding genes on the Y-chromosome including the SRY and the oncogene TSPY. According to the authors, the GBY locus may be hypomethylated in gonadoblastomas, resulting in overexpression of the TSPY and TTTY genes $(24,25)$. However, the significance of Y-chromosome loss for the development or progression of these tumors is still unknown.

In head and neck carcinomas, Y-chromosome loss was initially detected by GTG-banding analysis $(4,26)$. Using fluorescence in situ hybrization (FISH), Poetsch et al. (27) reported Y-chromosome loss in 53\% of oropharyngeal, hypopharyngeal and laryngeal squamous cell carcinomas, except in poorly differentiated carcinomas. In laryngeal carcinomas, Szyfter et al. (28) found frequent Y-chromosome loss. Kujawski et al. (29) reported Y-chromosome loss as a common alteration in cell lines derived from primary and recurrent head and neck carcinomas, in primary larynx tumors and their corresponding metastases, and in multiple primary tumors from the same head and neck region.

In a previous study, our group reported Y-chromosome loss as the most frequent alteration in head and neck tumors analyzed by G-banding (27 of 59 cases). Fourteen of 27 cases showed lymph node involvement and 15 of 27 died from the disease. These data suggested an association between Y nullisomy and poor clinical outcome (30). Based on these findings and on the evidence that $Y$-chromosome loss might be correlated with aging, we used a case-control study involving age-matched individuals in order to investigate this hypothesis.

\section{Material and Methods}

Twenty-one samples of primary head and neck tumors were surgically removed and obtained from Hospital A.C. Camargo, São Paulo, Brazil (Table 1). The control sample consisted of 16 men randomly selected from the general population with no evidence of cancer or a family history of cancer matched for age with cases (ranging from 28 to 68 years). Peripheral blood samples were collected from 13 cases and a mucosa smear was obtained from three cases. The control individuals were not tobacco or alcohol consumers. Informed consent was obtained from all patients and controls prior to sampling. The Conselho Nacional de Ética em Pesquisa (CONEP \#813/2000) approved this study. The medical records of all patients were examined to obtain clinical and histopathological data. First- and second-degree relatives with cancer were considered to be informative for family history. Whenever possible, the evidence for cancer was based on the medical records. None of the patients had undergone radiotherapy or chemotherapy before surgery. Histopathological classification was based on the International Classification of Diseases for Oncology of the World Health Organization (WHO) (31). Clinical stage was determined using the TNM (tumor, lymph nodes, metastasis) Staging System (32).

\section{Cytogenetic study}

Twenty-one fresh tumor samples were obtained under sterile conditions and immediately processed. Chromosome preparation and cytogenetic analysis were carried out using standard techniques following the direct harvesting of primary cultures. Metaphase chromosomes were processed for GTG-banding (33). The karyotype description and the requirements for clonality were based on the International System for Human Cytogenetic Nomenclature (ISCN) (34). A further requirement for clonality was the presence of chromosomal alterations in at least two culture flasks.

Normal cytogenetic controls were prepared from phytohemagglutinin-stimulated normal male lymphoblasts harvested for $72 \mathrm{~h}$ at $37^{\circ} \mathrm{C}$, as described by Moorhead et al. (35).

\section{Fluorescence in situ hybridization}

Suspension cells stored at $-20^{\circ} \mathrm{C}$ were used for FISH. Hybridization, suppression hybridization, detection, fluorescence microscopy, and microphotography were performed as previously described (36). Briefly, the slides were dehydrated in ethanol $(70,85$, and $100 \%)$ and air-dried. FISH was performed with a commercially available biotin-labeled centromeric probe for the Y-chromosome (LPE00YcG, Cytocell, UK) and a digoxigenin-labeled centromeric probe for chromosome 1 (LPE001R, Cytocell). Chromosome 1 is one of the most stable in human tumors, since it is not frequently found altered in head and neck cancer (37). For hybridization, $10 \mu \mathrm{L}$ of the probe was applied to each slide and denatured for $2 \min$ at $75^{\circ} \mathrm{C}$. Hybridization was performed for $1 \mathrm{~h}$ at $37^{\circ} \mathrm{C}$ in a dark chamber, after which the slides were rinsed in $0.25 \mathrm{XSC}$ at $42^{\circ} \mathrm{C}$ followed by $2 \mathrm{XSC} / \mathrm{Tw}$ ween 20 at room temperature.

On average, 341 interphase nuclei with intact morphology, based on 4,6-diamino-2-phenylindole (DAPI) counterstaining, were scored to determine the number of hybridiza- 
Table 1. Description of the 21 male patients studied according to age, histopathological diagnosis, TNM status, clinical data, and composite karyotype.

\begin{tabular}{|c|c|c|c|c|c|c|c|c|}
\hline Patient & $\begin{array}{c}\text { Age } \\
\text { (years) }\end{array}$ & Anatomic site & Grade & TNM & $\begin{array}{l}\text { Tobacco } \\
\text { use }\end{array}$ & $\begin{array}{l}\text { Alcohol } \\
\text { use }\end{array}$ & $\begin{array}{l}\text { Follow-up* } \\
\text { (months) }\end{array}$ & Composite karyotype \\
\hline 1 & 63 & Floor of the mouth & I & $\mathrm{T}_{3} \mathrm{~N}_{0} \mathrm{M}_{0}$ & + & - & DOC (97) & nd \\
\hline 2 & 67 & Glottic and infraglottic & 1 & $\mathrm{~T}_{3} \mathrm{~N}_{0} \mathrm{M}_{0}$ & + & + & ANR (200) & $47, \mathrm{XY},+2[3]$ \\
\hline 3 & 58 & Tongue & II & $\mathrm{T}_{3} \mathrm{~N}_{1} \mathrm{M}_{0}$ & + & + & DOC (94) & nd \\
\hline 4 & 39 & Retromolar & I & $\mathrm{T}_{4} \mathrm{~N}_{2 \mathrm{a}} \mathrm{M}_{0}$ & + & + & DOD (15) & $46, X Y[5]$ \\
\hline 5 & 60 & Palate & II & $\mathrm{T}_{4} \mathrm{~N}_{0} \mathrm{M}_{0}$ & + & - & $\mathrm{DOC}(36)$ & nd \\
\hline 6 & 68 & Tongue & 1 & $\mathrm{~T}_{3} \mathrm{~N}_{0} \mathrm{M}_{0}$ & + & + & DOC (99) & $40 \sim 46, X,-Y,-22[c p 9] / 46, X Y[4]$ \\
\hline 7 & 46 & Floor of the mouth & I & $\mathrm{T}_{4} \mathrm{~N}_{0} \mathrm{M}_{0}$ & + & + & DOD (18) & $\begin{array}{l}\text { 44 49,X,-Y,del(5)(q15q23),+8,-9,-13,-19, } \\
-21,+22,+\operatorname{mar}[\mathrm{cp} 10] / 46, \mathrm{XY}[10]\end{array}$ \\
\hline 8 & 58 & Gingiva & II & $\mathrm{T}_{4} \mathrm{~N}_{0} \mathrm{M}_{0}$ & + & + & DOD (52) & $46, \mathrm{XY}[7]$ \\
\hline 9 & 63 & Retromolar & I & $\mathrm{T}_{4} \mathrm{~N}_{1} \mathrm{M}_{0}$ & + & + & DOD (81.8) & nd \\
\hline 10 & 66 & Floor of the mouth & 1 & $\mathrm{~T}_{4} \mathrm{~N}_{0} \mathrm{M}_{0}$ & + & + & $\mathrm{DOC}(2 \mathrm{~d})$ & $41 \sim 45, X,-Y,+17,-20,+\operatorname{mar}[\mathrm{cp} 19] / 46, \mathrm{XY}[5]$ \\
\hline 11 & 35 & Tongue & II & $\mathrm{T}_{4} \mathrm{~N}_{0} \mathrm{M}_{0}$ & - & + & DOD (6) & $43 \sim 48, X Y,-9,+10,-17,+22[c p 15] / 46, X Y[21]$ \\
\hline 12 & 40 & Tongue & IV & $\mathrm{T}_{4} \mathrm{~N}_{2} \mathrm{M}_{0}$ & + & + & DOD (31) & $44 \sim 48, X,-Y,+10,+20,+22[\operatorname{cp} 10] / 46, X Y[17]$ \\
\hline 13 & 63 & Oropharynx & 1 & $\mathrm{~T}_{4} \mathrm{~N}_{0} \mathrm{M}_{0}$ & + & + & DOD (15) & $\begin{array}{l}41 \sim 48, X,-Y,+9, \text { add }(9)(p 24),+13,-18,-19, \\
+22[\mathrm{cp} 21] / 46, X Y[8]\end{array}$ \\
\hline 14 & 64 & Epiglottic & II & $\mathrm{T}_{3} \mathrm{~N}_{0} \mathrm{M}_{0}$ & + & + & ANR (183) & $\begin{array}{l}\text { 44 48,X,-Y,+7,-10,-21,+22,+del(22) } \\
\text { (q13.1)[7][cp20]/46,XY[9] }\end{array}$ \\
\hline 15 & 62 & Tonsil & II & $\mathrm{T}_{4} \mathrm{~N}_{2} \mathrm{M}_{0}$ & + & + & DOD (8) & $\begin{array}{l}\text { 42 47,X,-Y,-3,-15,+15,-17,-19,-22 } \\
\text { [cp17]/46,XY[17] }\end{array}$ \\
\hline 16 & 63 & Floor of the mouth & II & $\mathrm{T}_{2} \mathrm{~N}_{0} \mathrm{M}_{0}$ & - & - & DOD (126) & $\begin{array}{l}\text { 42 48,X,-Y,-3,-9,-14,-16,-18,-19,+22, } \\
+\operatorname{mar}[\mathrm{cp} 16] / 46, \mathrm{XY}[9]\end{array}$ \\
\hline 17 & 65 & Retromolar & II & $\mathrm{T}_{4} \mathrm{~N}_{2 \mathrm{~b}} \mathrm{M}_{0}$ & + & + & DOD (94) & $\begin{array}{l}43 \sim 47, X,-Y, \text { del }(1)(q 21),-9,-10, \operatorname{inv}(12) \\
(p 13.3 q 12),-17,-18,-21,+22 \\
+\operatorname{mar}[\mathrm{cp} 21] / 46, X Y[17]\end{array}$ \\
\hline 18 & 57 & Epiglottic & 1 & $\mathrm{~T}_{3} \mathrm{~N}_{2 \mathrm{c}} \mathrm{M}_{0}$ & + & + & $\mathrm{DOC}(21)$ & $\begin{array}{l}41 \sim 48, X,-Y,-4,+6,+\operatorname{del}(6)(q 22),-11,-12, \\
-15,-16,-19,-22,+? \operatorname{del}(22)(q 13.1) \\
+\operatorname{mar}[\operatorname{cp} 18] / 46, X Y[6]\end{array}$ \\
\hline 19 & 56 & Tonsil & II & $\mathrm{T}_{3} \mathrm{~N}_{2 \mathrm{c}} \mathrm{M}_{0}$ & + & + & ANR (183) & $\begin{array}{l}44 \sim 47, X,-Y,+7,-19,-20,+22,+\operatorname{mar}[\mathrm{cp} 17] / \\
46, \mathrm{XY}[1]\end{array}$ \\
\hline 20 & 65 & Larynx/transglottic & 1 & $\mathrm{~T}_{4} \mathrm{~N}_{0} \mathrm{M}_{0}$ & + & + & ANR (182) & $\begin{array}{l}\text { 44 49,XY, del(1)(q41),?add(4q),+20, } \\
\operatorname{del}(22)(q 13.1),+\operatorname{mar}[\operatorname{cp} 11] / 46, X Y[13]\end{array}$ \\
\hline 21 & 32 & Maxillary antrum & III & $\mathrm{T}_{4} \mathrm{~N}_{2} \mathrm{M}_{0}$ & - & + & DOD (20) & $\begin{array}{l}\text { 43 47,-X,-Y,del(6)(q21q23),+10, } \\
+22[\mathrm{cp} 11] / 46, \mathrm{XY}[6]\end{array}$ \\
\hline
\end{tabular}

*Months from surgery to July 2011. TNM = tumor, lymph nodes, metastasis; $(-)=$ negative history; $(+)=$ positive history; $d$ = days; DOC $=$ died from other causes; $\mathrm{DOD}=$ died of disease; $\mathrm{ANR}=$ alive with no recurrence; $\mathrm{nd}=$ not determined .

tion signals for the target probe and the frequencies of loss involving the $Y$-chromosome. A case was considered to have a numerical chromosome abnormality when the percentage of cells showing an abnormal number of hybridization signals was higher than the mean plus 2 standard deviations (2SD) obtained for the same chromosome in the matched normal control. Image analysis was performed using an Olympus BX61 microscope connected to the FISHView EXPO 2.0 software (Applied Spectral Imaging, USA). The guidelines used for FISH evaluation were those described by Hopman et al. (38). Slides were assessed in a blinded fashin by two observers (LCVC and NAB). Any discrepancy in sample classification was addressed by immediate review and the final result was reached by consensus.

The Kruskal-Wallis or Mann-Whitney test was applied to compare $\mathrm{Y}$ loss frequencies between groups. Analysis of correlation between $Y$ loss frequency and age was performed using the Spearman rank test.

\section{Results}

Twenty-one samples from male patients with head and neck carcinomas were investigated for Y-chromosome aneusomy in interphase nuclei. At least 100 interphase 
nuclei were analyzed, except in three cases (samples 12, 14, and 15). A high frequency of $\mathrm{Y}$-chromosome loss was observed, ranging from 11 to $85 \%$ (Table 2, Figures $1 A, B$ and 2). Considering a cut-off rate of $25 \%$ as significant, $Y$ chromosome loss was detected in 18 of the 21 cases analyzed.

G-banding results were previously obtained in 17 cases (33), 12 of whom presented Y-chromosome loss as part of a more complex abnormal karyotype (Table 1). FISH analysis confirmed $\mathrm{Y}$ loss in all cases previously studied by Gbanding, although 14 cases showed the alteration in more than $25 \%$ of cells.

To investigate the association between Y-chromosome loss and advanced age, 13 samples from normal individuals matched for age with the cases were evaluated. Y-chromosome loss was observed in 1 to $23 \%$ of the reference cells (Table 2). The normal mucosa from 3 healthy individuals revealed losses ranging from 14.7 to $30.8 \%$ of cells. When cases and the reference group were compared by age in periods of 5 years, a higher frequency of Y-chromosome loss was detected in head and neck patients compared to reference cases.

Tumor cases showed statistically higher frequencies of $Y$ loss compared to control and buccal smear controls $(P<0.0001)$. Y-chromosome loss was more frequently detected in tumors than in peripheral blood samples from controls $(P<0.0001)$ and buccal smear from healthy individuals $(P=0.0359$; Figure 1A). No correlation was observed between age and $\mathrm{Y}$-chromosome loss frequency in controls (peripheral blood and buccal smear) and tumor cases $(P$ $=0.1090, r=0.4160$, and $P=0.3398, r$ $=0.2192$, respectively, Spearman test; Figure 1B).

\section{Discussion}

Abnormal karyotypes have been reported in about 400 primary head and neck squamous cell carcinomas including clonal loss of the Y-chromosome (37). Although the significance of this alteration in the biology of the disease
Table 2. Loss of Y-chromosome by head and neck cancer patients and controls grouped by age using FISH analysis.

\begin{tabular}{|c|c|c|c|c|}
\hline Age groups & Age (years) & Case No. & Y loss/total No. cells & Frequency (\%) \\
\hline \multirow[t]{5}{*}{ 28-32 years } & 32 & Case 21 & $31 / 184$ & 17 \\
\hline & 28 & Control 1 & $5 / 534$ & 1 \\
\hline & 31 & Control 2 & $71 / 307$ & 23 \\
\hline & & Control $1+2$ & $76 / 841$ & 9 \\
\hline & 28 & Smear 1 & $22 / 149$ & 15 \\
\hline \multirow[t]{2}{*}{$33-37$ years } & 35 & Case 11 & $48 / 101$ & 47 \\
\hline & 37 & Control 3 & $84 / 684$ & 12 \\
\hline \multirow[t]{4}{*}{$38-42$ years } & 39 & Case 4 & $102 / 199$ & 51 \\
\hline & 40 & Case 12 & $52 / 93$ & 56 \\
\hline & 39 & Control 4 & $64 / 467$ & 14 \\
\hline & 41 & Smear 2 & $25 / 153$ & 16 \\
\hline \multirow[t]{2}{*}{$43-47$ years } & 46 & Case 7 & $147 / 674$ & 22 \\
\hline & 46 & Control 5 & $51 / 667$ & 8 \\
\hline \multirow[t]{3}{*}{$53-57$ years } & 56 & Case 19 & $55 / 216$ & 25 \\
\hline & 57 & Case 18 & $219 / 784$ & 28 \\
\hline & 57 & Control 6 & $42 / 529$ & 8 \\
\hline \multirow[t]{7}{*}{$58-62$ years } & 58 & Case 3 & $73 / 119$ & 61 \\
\hline & 58 & Case 8 & $350 / 411$ & 85 \\
\hline & 60 & Case 5 & $160 / 275$ & 58 \\
\hline & 62 & Case 15 & $25 / 57$ & 44 \\
\hline & 59 & Control 7 & $85 / 590$ & 14 \\
\hline & 64 & Control 8 & $82 / 593$ & 14 \\
\hline & & Control $7+8$ & $167 / 1183$ & 14 \\
\hline \multirow[t]{13}{*}{$63-67$ years } & 63 & Case 13 & $40 / 296$ & 13 \\
\hline & 63 & Case 16 & $38 / 100$ & 38 \\
\hline & 63 & Case 9 & $41 / 312$ & 13 \\
\hline & 64 & Case 14 & $16 / 44$ & 36 \\
\hline & 65 & Case 17 & $97 / 235$ & 41 \\
\hline & 65 & Case 10 & $58 / 100$ & 58 \\
\hline & 66 & Case 1 & $292 / 500$ & 58 \\
\hline & 66 & Case 10 & $105 / 123$ & 85 \\
\hline & 67 & Case 2 & $34 / 134$ & 25 \\
\hline & 64 & Control 9 & $88 / 593$ & 15 \\
\hline & 65 & Control 10 & $16 / 525$ & 3 \\
\hline & 68 & Control 11 & $72 / 450$ & 16 \\
\hline & & Control 9+10+11 & $176 / 1568$ & 11 \\
\hline \multirow[t]{5}{*}{$68-72$ years } & 68 & Case 6 & $137 / 232$ & 59 \\
\hline & 68 & Control 12 & $93 / 593$ & 16 \\
\hline & 68 & Control 13 & $103 / 450$ & 23 \\
\hline & & Control $12+13$ & $196 / 1043$ & 19 \\
\hline & 72 & Smear 3 & 29/159 & 18 \\
\hline
\end{tabular}


has remained elusive, recent studies have demonstrated that translation repression or mRNA degradation might also occur on the Y-chromosome. Recently two microRNAs (small RNAs that regulate gene expression) were identified on chromosomes $X$ and $Y(1)$. In an epigenetic profile of the euchromatic region of the human Y-chromosome, Singh et al. (23) observed in white blood cells that genes TSPY and TTTY mapped to the Y-chromosome appeared to be silenced by DNA methylation mechanisms. It is interesting to note that loss of methylation at this DNA locus has been
A

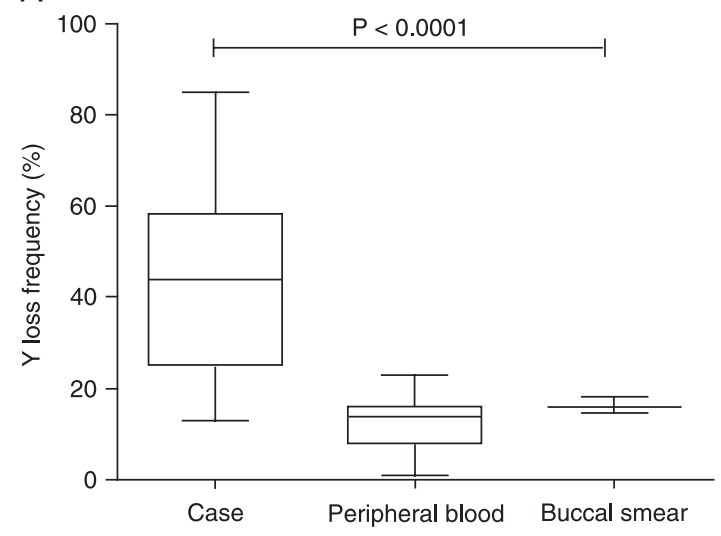

B

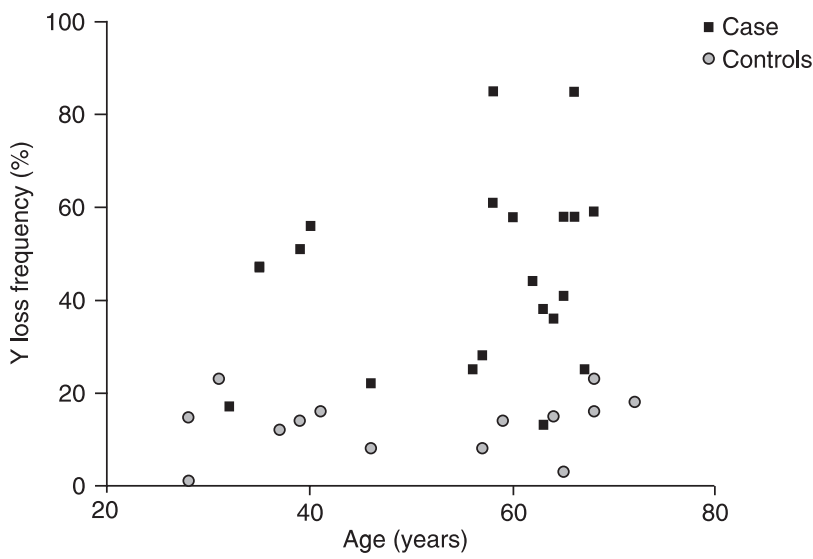

Figure 1. $A, Y$ loss frequency in tumor cases, peripheral blood and buccal smear from controls. The Kruskal-Wallis or Mann-Whitney test was applied to compare the frequency of Y-chromosome loss between groups. $B$, Correlation analysis between age and frequency of $Y$-chromosome loss in tumor cases $(P=0.3398, r=0.2192)$ and controls $(P=0.1090, r=0.4160)$ was performed using the Spearman rank test.

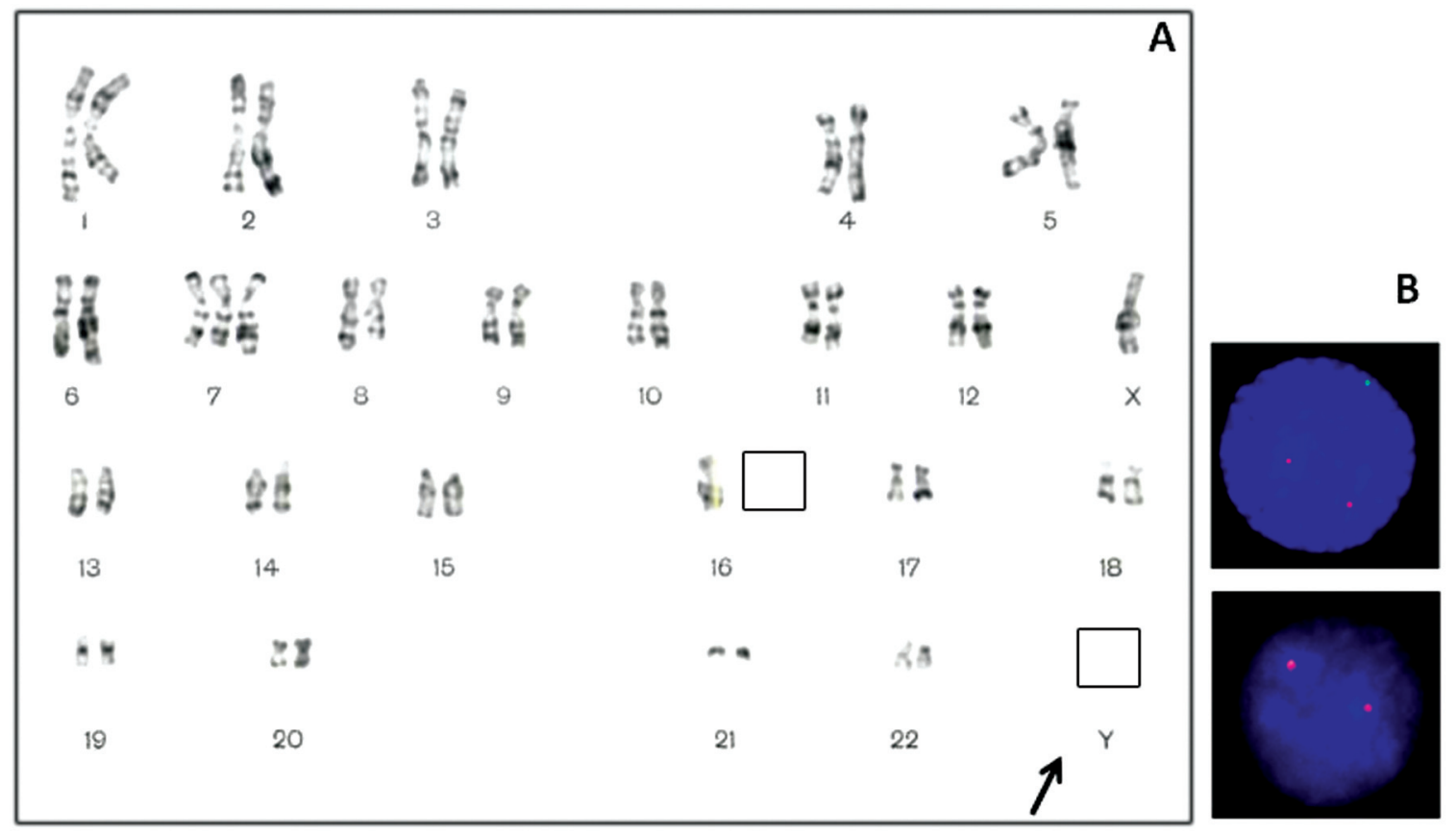

Figure 2. $A$, G-banded metaphase from a squamous cell carcinoma (case 14 ) with a $44, \mathrm{X},-\mathrm{Y},+7,-16$ karyotype. $B$, Interphase normal cell (peripheral lymphocyte) with two red signals (chromosome 1), one green signal (Y-chromosome) and one tumor nucleus showing loss of the Y-chromosome. 
observed in the promoters of oncogenes in cancer. These results revealed that genes mapped to the Y-chromosome could be considered as potential molecular markers in cancers.

In the present study, using dual-color FISH, it was demonstrated that Y-chromosome loss is age-independent and is a frequent chromosomal alteration in head and neck squamous cell carcinomas. As expected, older patients (>50 years old) were the most affected by the disease (17 of 21 male patients). All cases presented $Y$ aneusomy; however, in two younger patients (7 and 21) and in two older patients (9 and 13) this alteration was non-significant (cut-off of $25 \%$ as significant). Four patients of this study were alive without recurrence after a follow-up ranging from 182 to 200 months; all of them were older (>50 years old) and presented a significant loss of the Y-chromosome. Previously, in a large series of head and neck carcinomas evaluated by GTG-banding, loss of Y-chromosome was detected in 26 of $58(45 \%)$ head and neck carcinomas, 24 of which were T3-T4; 14 of 26 cases showed involvement of the lymph nodes and 16 of 26 died of the disease (30). Five patients aged $<50$ years showed loss of $Y$-chromosome; 4 of them were in stage T4 and two died of the disease. Although these data were not statistically significant, the authors showed a suggestive association between loss of the Y-chromosome and a poor outcome (30). Similarly, Kujawski et al. (29) were unable to find any correlation between Y-chromosome loss and disease progression and aggressiveness in head and neck carcinomas. However, the number of cases studied here is small for conclusions regarding the prognosis.

In addition, it was shown that the frequency of cells with $Y$ loss did not increase with age and was significantly higher in cases than in cancer-free individuals matched for age. These data suggest that $Y$ aneusomy is an event related to the disease. Regarding hematologic diseases, Wiktor et al. (6) reported an investigation of 185 male patients and 30 normal controls (aged 45-97 years) with $\mathrm{Y}$ loss as the only

\section{References}

1. Yuan Z, Sun X, Liu H, Xie J. MicroRNA genes derived from repetitive elements and expanded by segmental duplication events in mammalian genomes. PLoS One 2011; 6: e17666.

2. Lau YF. Gonadoblastoma, testicular and prostate cancers, and the TSPY gene. Am J Hum Genet 1999; 64: 921-927.

3. Nadal M, Pera G, Pujadas J, Abril J, Gonzalez L, Aguilo F, et al. Aneuploidy of chromosome $Y$ in prostate tumors and seminal vesicles: a possible sign of aging rather than an indicator of carcinogenesis? Mol Carcinog 2007; 46: 543552.

4. Jin Y, Mertens F, Mandahl N, Heim S, Olegard C, Wennerberg $\mathrm{J}$, et al. Chromosome abnormalities in eighty-three head and neck squamous cell carcinomas: influence of cytogenetic abnormality. They showed that $Y$ loss was significantly greater in cases, with only $10 \%$ of the controls showing a $>75 \%$ loss compared to $29 \%$ for those with disease.

In contrast, Jin et al. (26) reported that Y loss increased with advanced age in non-neoplastic upper aerodigestive tract mucosa. No Y-chromosome losses were detected in 15 samples from men aged more than 40 years, whereas $70 \%$ of the samples from men aged $60-79$ years displayed clonal loss of chromosome Y. However, none of the samples analyzed were subjected to histopathological analysis. In the present study, Y-chromosome loss was not correlated with aging in peripheral blood cells or in normal mucosa from healthy individuals.

It has been suggested that chromosome $Y$ has a tumor suppressor gene, the loss of which plays a role in the early steps of tumor development (39). Genes located on the Ychromosome appear to be involved in cell cycle regulation, signal transduction, cellular growth, and protein degradation (40), as well as in the regulation of gene expression (1). Mutations involving these genes could lead to carcinogenesis (2). Vijayakumar et al. (15) used a PC-3 cell line, which shows $Y$ aneusomy, to evaluate the effect of the addition of chromosome $\mathrm{Y}$ on the prostate tumorigenic phenotype in prostate cancer cells. The authors found tumorigenicity suppression suggesting the presence of a tumor suppressor gene mapped to the $\mathrm{Y}$-chromosome.

The present findings suggest the involvement of the Y-chromosome as a tumor-associated abnormality not related to age at the onset of head and neck cancer. Recent literature findings demonstrating that genes mapped to the Y-chromosome may act as regulators of gene expression as well as being controlled by epigenetic events make this chromosome an interesting target for the study of tumor markers.

\section{Acknowledgments}

Research supported by CNPq, CAPES, and FAPESP. culture conditions on karyotypic pattern. Cancer Res 1993; 53: $2140-2146$.

5. Stone JF, Sandberg AA. Sex chromosome aneuploidy and aging. Mutat Res 1995; 338: 107-113.

6. Wiktor A, Rybicki BA, Piao ZS, Shurafa M, Barthel B, Maeda $\mathrm{K}$, et al. Clinical significance of Y-chromosome loss in hematologic disease. Genes Chromosomes Cancer 2000; 27 : 11-16.

7. Pierre RV, Hoagland HC. Age-associated aneuploidy: loss of Y-chromosome from human bone marrow cells with aging. Cancer 1972; 30: 889-894.

8. Sakurai M, Sandberg AA. The chromosomes and causation of human cancer and leukemia. XVIII. The missing $Y$ in acute myeloblastic leukemia (AML) and Ph1-positive chronic 
myelocytic leukemia (CML). Cancer 1976; 38: 762-769.

9. United Kingdom Cancer Cytogenetics Group (UKCCG). Loss of the Y-chromosome from normal and neoplastic bone marrows. Genes Chromosomes Cancer 1992; 5: 83-88.

10. Zhang LJ, Shin ES, Yu ZX, Li SB. Molecular genetic evidence of $Y$-chromosome loss in male patients with hematological disorders. Chin Med J 2007; 120: 2002-2005.

11. Stahl PR, Kilgue A, Tennstedt P, Minner S, Krohn A, Simon $\mathrm{R}$, et al. Y-chromosome losses are exceedingly rare in prostate cancer and unrelated to patient age. Prostate 2011; doi: 10.1002/pros.21492 [Ahead of print].

12. Takahashi S, Alcaraz A, Brown JA, Borell TJ, Herath JF, Bergstralh EJ, et al. Aneusomies of chromosomes 8 and $Y$ detected by fluorescence in situ hybridization are prognostic markers for pathological stage C (pt3NOM0) prostate carcinoma. Clin Cancer Res 1996; 2: 137-145.

13. Tricoli JV. Y-chromosome enumeration in touch preparations from 42 prostate tumors by interphase fluorescence in situ hybridization analysis. Cancer Genet Cytogenet 1999; 111: 1-6.

14. Haapala K, Rokman A, Palmberg C, Hyytinen ER, Laurila M, Tammela TL, et al. Chromosomal changes in locally recurrent, hormone-refractory prostate carcinomas by karyotyping and comparative genomic hybridization. Cancer Genet Cytogenet 2001; 131: 74-78.

15. Vijayakumar S, Garcia D, Hensel CH, Banerjee M, Bracht T, Xiang R, et al. The human Y-chromosome suppresses the tumorigenicity of PC-3, a human prostate cancer cell line, in athymic nude mice. Genes Chromosomes Cancer 2005; 44: 365-372.

16. Park TS, Kim J, Song J, Choi JR. Non-age related Y-chromosome loss in an elderly patient with acute promyelocytic leukemia. Leuk Res 2009; 33: e114-e115.

17. Hunter S, Gramlich T, Abbott K, Varma V. Y-chromosome loss in esophageal carcinoma: an in situ hybridization study. Genes Chromosomes Cancer 1993; 8: 172-177.

18. Castedo S, Correia C, Gomes P, Seruca R, Soares P, Carneiro $\mathrm{F}$, et al. Loss of $\mathrm{Y}$-chromosome in gastric carcinoma. Fact or artifact? Cancer Genet Cytogenet 1992; 61: 39-41.

19. Bottarelli L, Azzoni C, Necchi F, Lagrasta C, Tamburini E, D'Adda T, et al. Sex chromosome alterations associate with tumor progression in sporadic colorectal carcinomas. Clin Cancer Res 2007; 13: 4365-4370.

20. Nathanson KL, Kanetsky PA, Hawes R, Vaughn DJ, Letrero $\mathrm{R}$, Tucker $\mathrm{K}$, et al. The $\mathrm{Y}$ deletion $\mathrm{gr} / \mathrm{gr}$ and susceptibility to testicular germ cell tumor. Am J Hum Genet 2005; 77: 10341043.

21. Al-Saleem T, Balsara BR, Liu Z, Feder M, Testa JR, Wu H, et al. Renal oncocytoma with loss of chromosomes $Y$ and 1 evolving to papillary carcinoma in connection with gain of chromosome 7. Coincidence or progression? Cancer Genet Cytogenet 2005; 163: 81-85.

22. Klatte T, Rao PN, de Martino M, LaRochelle J, Shuch B, Zomorodian N, et al. Cytogenetic profile predicts prognosis of patients with clear cell renal cell carcinoma. J Clin Oncol 2009; 27: 746-753

23. Singh NP, Madabhushi SR, Srivastava S, Senthilkumar R, Neeraja C, Khosla S, et al. Epigenetic profile of the euchromatic region of human Y-chromosome. Nucleic Acids Res 2011; 39: 3594-3606.
24. Jiang L, Gonda TA, Gamble MV, Salas M, Seshan V, Tu S, et al. Global hypomethylation of genomic DNA in cancer-associated myofibroblasts. Cancer Res 2008; 68: 9900-9908.

25. Irizarry RA, Ladd-Acosta C, Wen B, Wu Z, Montano C, Onyango $P$, et al. The human colon cancer methylome shows similar hypo- and hypermethylation at conserved tissuespecific CpG island shores. Nat Genet 2009; 41: 178-186.

26. Jin C, Jin Y, Wennerberg J, Akervall J, Grenthe B, Mandahl $\mathrm{N}$, et al. Clonal chromosome aberrations accumulate with age in upper aerodigestive tract mucosa. Mutat Res 1997; 374: 63-72.

27. Poetsch M, Kleist B, Lorenz G, Herrmann FH. Different numerical chromosomal aberrations detected by FISH in oropharyngeal, hypopharyngeal and laryngeal squamous cell carcinoma. Histopathology 1999; 34: 234-240.

28. Szyfter K, Szmeja Z, Szyfter W, Hemminki K, Banaszewski $\mathrm{J}$, Jaskula-Sztul R, et al. Molecular and cellular alterations in tobacco smoke-associated larynx cancer. Mutat Res 1999; 445: 259-274.

29. Kujawski M, Jarmuz M, Rydzanicz M, Szukala K, Wierzbicka $M$, Grenman R, et al. Frequent chromosome $Y$ loss in primary, second primary and metastatic squamous cell carcinomas of the head and neck region. Cancer Lett 2004; 208: 95-101.

30. Bergamo NA, da Silva Veiga LC, dos Reis PP, Nishimoto IN, Magrin J, Kowalski LP, et al. Classic and molecular cytogenetic analyses reveal chromosomal gains and losses correlated with survival in head and neck cancer patients. Clin Cancer Res 2005; 11: 621-631.

31. WHO (World Health Organization). International classification of diseases for oncology. Geneva: World Health Organization; 1990.

32. Sobin $\mathrm{LH}$, Wittelind $\mathrm{CH}$. International union against cancer: TNM classification of malignant tumours. 6th edn. New York: Wiley; 2002.

33. Scheres VMJC. Identification of two Robertsonian translocations with a Giemsa technique. Human Genet 1972; 15: 253-256.

34. Shaffer LG, Slovak ML, Campbell LJ. ISCN an international system for human cytogenetic nomenclature. Basel: Skarger; 1999.

35. Moorhead PS, Nowell PC, Mellman WJ, Battips DM, Hungerford D. Chromosome preparations of leukocytes cultured from human peripheral blood. Exp Cell Res 1960; 20: 613616.

36. Dracopoli NC. Current protocols in human genetics. New York: John Wiley \& Sons, Inc. (CD version); 2000.

37. Mitelman F, Johansson B, Mertens F. Mitelman database of chromosome aberrations and gene fusions in cancer. http:// cgap.nci.nih.gov/Chromosomes/Mitelman 2011.

38. Hopman AHN, Ramaekers FCS, Vooijs GP. Interphase cytogenetics of solid tumours. In: Polak JN, McGee JOJ (Editors), In situ hybridization: principles and practice. Oxford: Oxford University Press; 1992. p 165-186.

39. Logan JA, Seizinger BR, Atkins L, Martuza RL. Loss of the Y-chromosome in meningiomas. A molecular genetic approach. Cancer Genet Cytogenet 1990; 45: 41-47.

40. Tsuchiya K, Reijo R, Page DC, Disteche CM. Gonadoblastoma: molecular definition of the susceptibility region on the Y-chromosome. Am J Hum Genet 1995; 57: 1400-1407. 